\title{
PENERAPAN MANAJEMEN STRATEGIK DALAM MENINGKATKAN MUTU PENDIDIKAN MADRASAH
}

\author{
Wiwin Mistiani
}

\begin{abstract}
In its dedodquet, madrasas have undegonevarious dhanges, namily from the pesantren leaming system to themadrasa system fromtraditional to dassical mithoos; from halaqah system to bendhes, desks and bladkboards; from traditional to mokm aumiala; from dassical education to modam educational reform the dange indiates the existence of process or efforts of dedopment of madrasah education in the dreetion of moreadranced, qualified and competitive from time to time Coneptually, ane way to improve the quality of eluration and competitiveness of madrasah in the era of gdoalization competition is to implement strategicmanagement which indudes 4 stages such as environmental analysis, formulating implementing and evaluating strategic deeisions between functions that enablean arganization to adieve its goals in the future Strategic Managemett is based on the entire scope of the work. Thus it can beutilized wel for makronya enironment for example in govemment management and also can be utilized also for in mikronya eniromment for example in company management or arganization or pengdoalan Madrasah. However, it should be undastood only here that in the use of macro and micro scopetherearea number of fundamental differences suchas thefollowingexposures
\end{abstract}

Keywords: manajemen strategic, peningkatan mutu, madrasah 


\section{Pendahuluan}

Madrasah sebagai salah satu pusat pelaksana kegiatan pendidikan keislaman merupakan lembaga yang memiliki peran yang sangat penting dalam mencetak generasi Indonesia yang cerdas, bertakwa kepada Allah SWT dan berakhlak mulia. Madrasah akan berjalan maksimal bahkan akan sejajar serta dapat bersaing dengan dengan sekolah umum yang berkulaitas di Indonesia manakala didukung oleh manajemen yang baik, Sumber daya Manusia yang unggul, sarana dan prasarana serta pembiayaan yang memadai. Penerapan peraturan dan sistem manajemen yang baku dalam lembaga pendidikan khususnya di madrasah tentunya sangat dibutuhkan dalam upaya pemaksimalan potensi yang ada dalam seluruh komponen yang di miliki 0leh madrasah. Madrasah yang unggul dan bermutu berkolerasi terhadap peningkatan sumber daya manusia yang berkualitas. Semakin baik mutu sebuah madrasah idealnya akan menghasilkan input, proses dan output yang baik pula. Karena pada dasarnya perkembangan arus globalisasi yang terjadi saat ini cenderung menimbulkan permasalahan dan tantangan - tantangan baru yang bervariasi dan intesitasnya cenderung meningkat. Keadaan itu akan membawa dampak luas dan bervariasinya tugas-tugas pengelola madrasah.

Menurut ahmad khori Para pengelola pendidikan saat ini belum mampu mengamati dan merespon segenap tantangan yang dimunculkan oleh lingkungan eksternal baik yang dekat maupun yang jauh. Lingkungan ekstrenal yang dekat adalah keadaan yang mempunyai pengaruh langsung terhadap operasional lembaga seperti berbagai potensi dan keadaan, situasi persaingan, pelangan pendidikan dan penguna lulusan. Sementara itu, Lingkungan eksternal yang jauh adalah berbagai kekuatan dan kondisi yang muncul di luar lingkungan eksternal yang dekat meliputi keadaan social ekonomi, politik, keamanan perkembngan teknologi dan persaingan global secara tidak langsung sangat berpengaruh terhadap pengeloaan pendidikan. ${ }^{1}$

Oleh sebab itu madrasah sebagai salah satu institusi pendidikan islam harus mampu berfikir kreatif dan inovatif serta responsive dalam mengembangakan pendidikan agar tidak jauh tertinggal dengan sekolah umum lainya.

${ }^{1}$ Ahmad khori, Manajemen strategic dan mutu pendidikan, Vol. 1 no. 1 Mei 2016 
Salah satu cara yang dapat dilakukan dalam upaya meningkatan mutu, dan daya saing yaitu dengan menerapkan manajemen strategik. Menurut Fred R. David Manajemen Strategik adalah ilmu mengenai perumusan, pelaksanaan dan evaluasi keputusan-keputusan lintas fungsi yang memungkinkan organisasi mencapai tujuannya. lebih lanjut Menurut Husein Umar Manajemen strategik sebagai suatu seni dan ilmu dalam hal pembuatan (formilating, penerapan (implementing dan evaluasi (ealuating keputusan- keputusan startegis antara fungsi yang memungkinkan sebuah organisasi mencapai tujuannya pada masa mendatang. ${ }^{2}$ Sementara itu, Menurut Murniati Manajemen Strategik sebagai kegiatan yang harus dilakukan oleh manajemen puncak bersama secara terus menerus dan merupakan siklus yang mampu melahirkan keputusan untuk memenuhi relevansi kebutuhan organisasi dalam kebutuhan lingkungan. ${ }^{3}$

Dalam kontek ini melalui manajemen strategi pimpinan madrasah harus mampu merumuskan dan menentukan strategi madrasah yang tepat sehingga tersebut tidak hanya mampu mempertahankan eksistensinya akan tetapi mampu penyesuaikan dengan kebutuhan masyarakat dan dapat bersaing dengan Madrasah/ sekolah maju lainya.

Ada beberapa permasalahan yang menarik penulis untuk mengangkat permasalah ini yang pertama adalah rendahnya mutu pendidikan dan daya saing Madrasah terutama di wilayah tengah dan timur Indonesia, masyarakat lebih percaya percaya dengan sekolah Oleh karena itu dalam makalah ini penulis akan menguraikan tentang konsep manajemen strategi, serta bagaimana penerapan Manajemen strategic dimadrasah dalam upaya meningkatkan mutu dan daya saing Madrasah di Indonesia.

\section{Defenisi Manajemen Strategik}

Ilmu manajemen adalah ilmu yang turut berkembang pesat sehingga Ilmu tersebut memiliki beragam cabang dan beberapa kajian yang bersifat khusus misalnya ialah manajemen keuangan, manajemen sumber daya manusia, manajemen produksi,

\footnotetext{
${ }^{2}$ David, Fred.R., Strategic Management, Seventh Edition (New Jersey, Prentice Hall International, Inc. 2004), 5

3 Murniati \&Usman, N. Implementasi Manajemen Stratejik Dalam Pemberdayaan Sekolah Menengah Kejuruan. Bandung: Citapustaka Media Perintis, 2009) 46
} 
manajemen transportasi, dan muncul kajian khusus yang lain yaitu Manajemen Strategik.

Pengertian umum strategi yaitu suatu proses yang menentukan adanya perencanaan terhadap para top manajer dalam hal ini penetu kebijakan/ Kepala madrasah yang sungguh berarah pada tujuan jangka panjang yang disertai dengan penyusunan akan upaya bagaimana agar mencapai tujuan yang diharapkan. Sementara Pengertian khusus strategi yaitu suatu tindakan yang bersifat terus-menerus mengalami peningkatan dan dilakukan sesuai dengan sudut pandang tentang apa yang diinginkan serta diharapkan oleh para konsumen/ pelangan/steakholder untuk di masa depan. D engan strategi ini maka ada yang hampir dimulai dari apa yang selalu untuk bisa terjadi dan bukan yang dimulai dari apa yang terjadi.

Sementara itu, Menurut D avid Manajemen Strategik adalah ilmu mengenai perumusan, pelaksanaan dan evaluasi keputusankeputusan lintas fungsi yang memungkinkan organisasi mencapai tujuannya. ${ }^{4}$ Sedangkan menurut Husain Umar manajemen strategic adalah sebagai suatu seni dan ilmu dalam hal pembuatan (fomlating, penerapan (implementing dan evaluasi (evaluating keputusan- keputusan startegis antara fungsi yang memungkinkan sebuah organisasi mencapai tujuannya pada masa mendatang. ${ }^{5}$

Manajemen strategik ini juga suatu sistem yang digunakan sebagai satu kesatuan dalam memiliki beragam komponen saling berkaitan dan mempengaruhi antara satu dan lainnya serta bergerak secara serentak menuju arah yang sama pula. Bagian ilmu Manajemen Strategik ini senantiasa akan menyikapi pada dinamikadinamika yang terjadi baik itu dari lingkungan internal maupun eksternalnya yang kemudian akan berlanjut dengan bagaimana cara berupaya untuk menyesuaikan hingga pada akhirnya pada tujuan yang telah ditetapkan itu dapat segera terlaksana atau direalisasikan dengan baik.

Manajemen Strategik berdasarkan pada seluruh ruang lingkup pekerjaannya. D engan demikian dapat dimanfaatkan secara baik untuk lingkungan makronya misalnya di dalam manajemen

${ }^{4}$ David, Fred.R., Strategic Management, Seventh Edition (, New Jersey, Prentice Hall International, Inc. 2004), 5

5 Taufiqurahman, Manajemen strategic, (Jakarta: Fakultas ilmu social dan politik, Universitas Prof. Dr. Moestopo Beragama 2016), 15 
pemerintahan dan juga dapat dimanfaatkan pula untuk di lingkungan mikronya misalnya di dalam manajemen perusahaan atau organisasi atau pengeloalan Madrasah. Akan tetapi di sini hanya perlu dipahami bahwa di dalam penggunaan ruang lingkup makro dan mikro ada sejumlah perbedaan yang begitu mendasar seperti paparan berikut ini.

Kebijakan makro yang harus digunakan dan diperhatikan yaitu subyek dan objek dalam suatu manajemen tersebut adalah yang berupa para masyarakat yang bersifat aggeegte, sedangkan untuk ruang lingkup mikro maka perhatiannya pun terhadap subyek dan obyek di suatu manajemen berupa individual rumah tangga perusahaan atau para pelanggan yang memakai hasil produksi. Di samping itu mengenai prinsip kerja untuk manajemen strategik makro kemungkinannya perhatian mengarah pada efektivitas, sedangkan pada manajemen strategik yang rangkumannya secara mikro maka harus sesuai kepada prinsip kerja efisiensinya.

\section{Karakteristik Manajemen Strategik}

Pada umumnya manajemen ini sungguh berbeda dengan lainnya dimana manajemen strategi ini senantiasa menyikapi dinamika terjadinya suatu perubahan lingkungan sehingga bisa mempengaruhi terhadap implementasi manajemen itu sendiri serta berupaya untuk merealisasikan tujuan yang telah ditetapkan dengan sejalan pada hal tersebut maka berikut ini akan ditunjukkan karakteristik manajemen strategik :

a) Manajemen strategik bersifat jangka panjang

b) Manajemen strategik bersifat dinamik

c) Manajemen strategik merupakan sesuatu yang berpadu oleh manajemen operasional

d) Manajemen strategik perlu dimotori oleh unsur-unsur pada manajer tingkat puncak

e) Manajemen strategik berorientasi dan mendekati untuk masa depan

f) Manajemen strategik senantiasa harus didorong dan didukung dalam pelaksanaannya oleh semua sumber daya ekonomi yang tersedia $^{6}$

${ }^{6}$ Taufiqurahman, Manajemen strategic, (Jakarta: Fakultas ilmu social dan politik, Universitas Prof. Dr Moestopo Beragama 2016), h.15 


\section{Penerapan Manajemen Strategik di Madrasah}

Terdapat tiga pertanyaan yang mendasari setiap gerak langkah perencanaan strategis, yaitu: a) Di manakah posisi Madrasah saat ini?; b) Ke mana Madrasah akan diarahkan?: c) Bagaimana cara Madrasah bisa mencapai tujuan yang diharapkan?

Para pakar berbeda pandangan mengenai konsepsi mutu. Namun, pada dekade ini terdapat tiga konsepsi mutu yang paling populer yaitu, W. Edwards D eming, Philip B. Crosby, dan Joseph M. Juran. W. Edwards. Deming mendefinisikan mutu adalah semua kebutuhan dan keinginan pelanggan. Philip B. Crosby mendefinisikan mutu sebagai kesesuaian terhadap persyaratan. Sedangkan Joseph M. Juran mendefinisikan mutu sebagai kesesuaian terhadap spesifikasi.. ${ }^{7}$ Kualitas dapat berarti keunggulan, dapat jug berarti pemenuhan harapan pelanggan. Hansen sebagaimana dikutip Naronha, menyayangkan bahwa sampai saat ini konsep kualitas diartikan terfragmentasi dan ambigu baik dalam literatur maupun dalam praktik. Setelah melakukan pencarian literatur Hansen telah mengidentifikasi lima definisi utama yaitu, kualitas sebagai produk, kualitas sebagai mana pandangan konsumen, kualitas sebagai pemenuhan harapan pelanggan, kualitas sebagai nilai, dan kualitas sebagai adaptasi terhadap teknis spesifikasi atau manufaktur.

Orientasi pada mutu merupakan langkah strategis yang harus di capai oleh madrasah sebagai intitusi pendidikan yang akan melahirkan generasi penerus bangsa. Lebih lanjut Istilah madrasah berasal dari bahasa Arab yang memiliki arti "tempat belajar". Kata "madrasah" dalam bahasa Arab adalah bentuk kata "keterangan tempat" dari akar kata "darasa". D engan demikian, secara harfiah "madrasah" dapat diartikan sebagai "tempat belajar" atau "tempat untuk memberikan pelajaran". ${ }^{8}$ Selanjutnya, dalam bahasa Indonesia, kata "madrasah" sudah sangat lazim dan dipahami dan diartikan sebagai "sekolah", meskipun kata "sekolah" itu sendiri bukan berasal dari bahasa Indonesia, melainkan dari bahasa asing "schod".

${ }^{7}$ Hanun Asrohah, manajemen mutu pendidikan, Buku Perkuliahan Program S-1 Jurusan Kependikan Islam Fakultas Tarbiyah dan Kependidikan UIN Sunan Ampel Surabaya, h. 17

${ }^{8}$ Haidar Putra Daulay.. Historisitas dan Eksistensi (Pesantren, Sekolah dan Madrasah). (Yogyakarta: PT. Tiara Wacana, 2001.) h. 59. 
D alam bahasa Indonesia, kata "madrasah" tetap dipakai dengan kata aslinya yakni "madrasah" yang diartikan sebagai lembaga pendidikan tingkat dasar dan menengah. Dalam pengertian yang lebih luas, madrasah mengandung arti tempat atau wahana proses belajar

mengajar yang dilakukan secara terarah, terpimpin dan terkendali berbasiskan nilai-nilai ajaran Islam. Secara teknis, pembelajaran di madrasah menggambarkan proses pembelajaran secara formal yang tidak berbeda dengan sekolah pada umumnya, namun secara kultural, madrasah memiliki spesifikasi atau karakteristik yakni pembelajaran yang bertumpu pada pengembangan substansi ajaran Islam. $^{9}$

Dalam perkembangannya, madrasah telah mengalami berbagai perubahan yakni dari sistem pembelajaran pesantren ke sistem madrasah; dari metode tradisional ke klasikal; dari sistem halaqahke bangku, meja dan papan tulis; dari kurikulum tradisional ke modern; dari pendidikan klasik ke pembaharuan pendidikan yang modern. ${ }^{10}$

Berbagai perubahan tersebut menunjukkan adanya proses atau upaya pembangunan pendidikan madrasah ke arah yang lebih maju, bermutu serta berdaya saing dari waktu ke waktu. Secara konseptual, salah satu cara untuk meningkatkan mutu pendidikan dan daya saing adalah dengan inovasi, meskipun konsep ini tidaklah mudah diterapkan pada tataran empiris. Kata inovasi berasal dari bahasa Inggris "inmovation" yang berarti pembaruan, atau penemuan baru. Dalam Kamus Sosiologi, inovasi dimaknai dengan penemuan baru pada unsur kebudayaan masyarakat. Atas dasar pengertian ini maka daya saing pendidikan madrasah dapat dilakukan dengan memperbarui atau memperbaiki berbagai faktor yang dapat berdampak langsung atau tidak langsung terhadap kualitas pendidikan madrasah. Salah satunya dengan menerapkan manajemen strategic.

\footnotetext{
${ }^{9}$ Masykuri dkk. Profil MadrasahTsanawiyah. Jakarta: Departemen Agama RI, Direktorat Jenderal Kelembagaan Agama Islam, 2005. h. 2.

${ }^{10}$ Badri Yatim, dkk. Sejarah Perkembangan Madrasah. (Jakarta: Departemen Agama RI Direktorat Jenderal Pembinaan Kelembagaan Agama Islam, 2000.) h 34
} 
Ada 4 empat tahapan manajemen strategik yang dapat diterapkan oleh madrasah dalam upaya peningkatan mutu dan daya saing diantaranya yaitu,

Petam, Melakukan Analisis lingkungan. pada tahap ini kepala madrasah serta stap dan dewan guru melakukan analisis lingkungan dimana kepala madrasah melakukan suatu proses monitoring terhadap lingkungan sekitar Madrasah yang bertujuan untuk mengidentifikasikan peluang (qportunities) dan tantangan (thread) yang mempengaruhi kemampuan madrasah untuk mencapai tujuannya.

Tujuan dilakukan analisis lingkungan adalah untuk mengantisipasi lingkungan madrasah sehingga dapat bereaksi secara cepat dan tepat untuk mensukseskan pengelolaan Madrasah. Analisis lingkungan ini juga merupakan suatu proses yang digunakan dalam membuat perencanan-perencanaan strategi untuk memantau lingkungan dalam menentukan peluang atau ancaman. ${ }^{11}$

Sementara itu menurut murniati Pengamatan lingkungan merupakan serangkaian gambaran kondisi lingkungan organisasi yang meliputi lingkungan internal dan eksternal. Lingkungan internal meliputi "variable kekuatan dan kelemahan yang meliputi struktur, budaya, dan sumber daya organisasi" ${ }^{12}$ Lebih lanjut, Siagian membagi lingkungan eksternal kedalam dua bagian yaitu: Lingkungan eksternal dekat dan lingkungan eksternal jauh. ${ }^{13}$ Lingkungan eksternal dekat merupakan lingkungan yang mempunyai dampak pada kegiatan kegiatan operasional organisasi seperti berbagai kekuatan dan kondisi dalam lingkup dimana organisasi bergerak, situasi persaingan, situasi pasar dan sebagainya. Sedangkan lingkungan eksternal jauh dapat bersifat politik, ekonomi, teknologi, keamanan, hukum, sosial budaya, pendidikan dan kultur masyarakat luas yang secara tidak langsung mempengaruhi kegiatan operasional organisasi. Analisis lingkungan

11 Taufiqurahman, Manajemen strategic, (Jakarta: Fakultas ilmu social dan politik, Universitas Prof. Dr. Moestopo Beragama 2016), 15

12 Murniati \&Usman, N. Implementasi Manajemen Stratejik Dalam Pemberdayaan Sekolah Menengah Kejuruan. ( Bandung: Cita pustaka Media Perintis, 2009) 46

${ }^{13}$ Siagian, Sondang. P. Manajemen Stratejik. (Jakarta: Bumi Aksara, 2012). 33 
eksternal juga dapat diartikan sebagai aktivitas memonitor dan mengevaluasi lingkungan eksternal dan internal organisasi kepada orang-orang penting yang ada dalam lingkungan Madrasah. Lingkungan eksternal dibedakan atas lingkungan makro dan lingkungan industri. Untuk lingkungan tersebut menggunakan metode SWOT (Strengh and lingkungan internal, Oppatunities and Threats untuk analisa lingkungan eksternal). Lingkungan makro merupakan lingkungan yang secara tidak langsung mempengaruhi keputusan-keputusan strategi madrasah dalam jangka panjang.

Langkah Kedua yang dapat dilakukan dalam penerapan manajemen strategic adalah Melakukan Perumusan strategik atau formulasi strategic, yang merupakan proses penyusunan langkahlangkah ke depan mencakup pengembangan visi dan misi, identifikasi peluang dan ancaman eksternal suatu organisasi, kesadaran akan kekuatan dan kelemahan internal, penetapan tujuan jangka panjang, penetapan tujuan strategik dan keuangan madrasah, serta merancang strategi untuk mencapai tujuan organisasi dalam rangka menyediakan astamer valueterbaik.

D alam hal penyusunan strategi, Fred R. D avid membagi proses ke dalam tiga tahapan aktivitas, yaitu: imput stage, matching stage, dan deision stage ${ }^{14}$ Termasuk di dalam formulasi strategi adalah pembahasan tentang bisnis baru yang akan dimasuki, bisnis yang dihentikan, alokasi sumber-sumber yang dimiliki, apakah akan melakukan ekspansi atau diversifikasi usaha, apakah akan memasuki pasar internasional, apakah akan melakukan merjer atau membentuk jaint-venture, serta bagaimana untuk menghindari pangambilalihan secara paksa (hosile takever). Ada 4 Proses perumusan visi yaitu :

a) menentukan rentang waktu dan lingkup analisis secara tepat

b) mengidentifikasi trend sosial, ekonomi, politik, dan teknologi yang akan mempengaruhi masa depan

c) Identifikasi kondisi persaingan

d) Evaluasi sumber daya dan kapabilitas internal. ${ }^{15}$

Selanjutnya menurut Morrisey dalam mengemukakan bahwa dalam membuat rumusan visi sebaiknya "kurang dari sepuluh kata, menarik perhatian, mudah diingat, memberi

\footnotetext{
${ }^{14}$ Taufiqurahman, Manajemen strategic, 27

${ }^{15}$ Ibid.
} 
inspirasi dan tantangan prestasi di masa mendatang dan konsisten dengan nilai strategis serta misi organisasi" ${ }^{16}$ Secara teoretis, pernyataan visi menyatakan "tujuan yang ingin dicapai sebuah organisasi (what we want to be sedangkan pernyataan misi menjawab pertanyaan apa sebabnya kita ada (nhy weexist) atau apa yang kita percayai dapat kita lakukan (what we bdieve we can do)" ${ }^{17}$ Perencanaan pendidikan untuk visi keunggulan sekolah menurut Anwar haruslah selaras dengan hakikat "pembaharuan pendidikan dengan mempertimbangkan pendekatan supply diveke pendekatan demand divesehingga sekolah memiliki senseof quality ${ }^{18}$ D alam penyusunan visi dan misi juga perlu diperhatikan "sejarah, preferensi masa kini, lingkungan pasar, sumber daya dan kompetensi yang membedakan antara satu organisasi dengan organisasi lainnya" ${ }^{\prime 19}$

Langkah Ketiga dalam manajemen stratejic adalah Mengimplementasikan manajemen strategik dalam peneglolaan madrasah. Implementasi manajemen strategic ini sering kali disebut tahap aksi yang merupakan perwujudan dari programprogram yang telah ditetapkan dalam proses perumusan strategik" Ada beberapa hal yang harus diperhatikan dalam proses implementasi yaitu program, anggaran dan prosedur.

Program merupakan langkah yang diperlukan untuk melaksanakan perencanaan sedangkan prosedur merupakan langkah penyelenggaraan program yang telah diurutkan secara sistematis.Anggaran merupakan biaya program yang dinyatakan dalam bentuk satuan uang. ${ }^{20}$ Yang meliputi penentuan sasaran tahunan, pengelolaan kebijakan, pemotivasian pegawai, pengalokasian sumber-sumber agar strategi yang diformulasikan dapat dilaksanakan. Termasuk di dalamnya adalah pengembangan kultur yang mendukung strategi, struktur organisasi yang efektif, pengarahan usaha-usaha pemasaran, penyiapan anggaran, pengembangan dan pemanfaatan sistem informasi, serta

${ }^{16}$ Anwar, M. Idochi. (2013). Administrasi Pendidikan dan

Manajemen Biaya Pendidikan. Jakarta:Raja Grafindo Persada 2013) 8

17 David, Fred R. (2009). Manajemen Strategik. (Jakarta: Salemba Empat. 2009 ) 16.

${ }^{18}$ Anwar Administrasi Pendidikan,13

${ }^{19}$ Shadrina, Adilah. Pentingnya Peran Visi dan Misi. Diakses dari www. dilahshadrina. blogspot.com /2013, Pada tanggal 13 April. 2018

${ }^{20}$ Murniati \&Usman, N. Implementasi Manajemen, 50 
mengkaitkan kompensasi pegawai dengan kinerja organisasi. Pada tahap ini, ketrampilan interpersonal sangatlah berperan. Sebagaimana Carl von Clausewitzdalam bukunya yang diterbitkan kembali On War, strategi bukanlah sekedar aktivitas prodemsdving tetapi lebih dari itu strategi bersifat terbuka (open-ended) dan kreatif untuk mempertajam masa depan dalam model dain of command di mana suatu strategi harus dijalankan setepat mungkin (menghindari bias-bias yang tidak perlu dalam setiap bagian struktur organisasi). ${ }^{21}$

Pada Aspek Implementasi manajemen strategic madrasah melakukan melalui serangkaian aktivitas dengan membuat prosedur kerja yang dideskripsikan melalui:

a) kondisi lingkungan internal yang terdiri dari membuat struktur organisasi , teamuak dan pembagian Job, hari dan waktu belajar, aset pembiayaan, kurikulum, promosi Madrasah, penerimaan mahasiswa baru, budaya dan kode etik, dan kebijakan Madrasah,

b) kondisi lingkungan eksternal sekolah meliputi lingkungan geografis, demografis, lingkungan budaya dan apresiasi masyarakat, regulasi pemerintah, ilmu pengetahuan dan teknologi, komite sekolah, lembaga mitra dan alumni

Implementasi strategik dalam upaya memenuhi standar pendidikan nasional. Struktur Madrasah tersebut harus menggambarkan kejelasan hubungan kerjasama dan kewenangan dalam organisasi setiap sub bagian Madrasah. Secara fungsional, struktur organisasi Madrasah harus memperjelas adanya pembagian tugas (job descrimadrasahion) yang jelas yang didasarkan pada kewenangan personil dalam mengelola dan mengembangkan bidang pengelolaan Madrasah yang telah disandangkan pada struktur jabatan yang tertera.

Dengan demikian, struktur organisasi madrasah yang dibuat telah menjelaskan adanya hubungan koordinasi dan teamwork yang dibentuk berdasarkan bidang keahlian dalam mengelola Madrasah. Anwar mengemukakan bahwa proses pendidikan yang bermutu merujuk pada: Kebermutuan subsistem dalam system proses yang mengacu pada ukuran kemampuan sistem dalam melaksanakan apa yang seharusnya dikerjakan, subsitem komunikasi yang berfungsi dalam memproses dan memeberikan informasi, dan susbsistem

${ }^{21}$ Taufiqurahman, Manajemen strategic, 28 
monitoring sebagai control sistem terjadap kegiatan dan akuntabilitas subsistem dalam hubungan sinergisnya di seluruh sistem $^{22}$. Selanjutnya, temuork dan pembagian tugas pada setiap bagian dijelaskan dalam paduan kerja pengelola Madrasah dimana masing-masing memiliki tanggung jawab, kewenangan dan tugas yang harus dikerjakan baik harian, mingguan, bulanan, semesteran, awal tahun dan akhir tahun pelajaran. Kurikulum yang dipakai harus mengacu pada pengembangan kurikulum Terbaru yaitu kurikulum 2013. Yang memuat pendidikan pada aspek jasmani, aspek akal dan ruhani.

Dalam pelaksanaan pembelajaran dalam konsep strategic proses belajar harus dibuat mudah dan menyenangkan agar peserta didik tidak tertekan secara psikologis dan tidak bosan. Hal ini sesuai dengan hadis rasululah. Dari anas bin malik dari nabi SAW "mudahkanlah dan jangan kau persulit. G embirakanlah dan jagan kau membuat lari ( $\mathrm{HR}$. Abu abdilah muhamad bin ismail al bukhori) $^{23}$. Oleh karena itu seorang pendidik harus mampu mengelola kelas dengan baik dan harus mampu mengunakan variasi metode sesuai dengan situasi kondisi dan karakteristik mata pelajaran yang diajarkan. Menurut achmad sanusi konsep pembelajaran dalam manajemen strategic dapat dikategorikan menjadi tiga yaitu (1) harus berkaitan dengan paradigm baru, (2) konsep multiple intelegensi (3) konsep berfikir. ${ }^{24}$

Pada aspek Penyelenggaraan promosi dan penerimaan mahasiswa baru dilakukan melalui publikasi media elektronik dan cetak. Ada dua variabel penting dalam penerapan strategi melalui "pemasaran yaitu segmentasi pasar (marke segmentation) yang merupakan pembagian pasar menjadi bagian-bagian konsumen yang berbeda menurut kebutuhan dan pemosisian produk (product positioning yang merupakan upaya untuk mengetahui apa yang diinginkan dan diharapkan konsumen" ${ }^{25}$ D epartemen Pendidikan dan Budaya (Muhaimin, yang mengemukakan bahwa "masukan

${ }^{22}$ Anwar, Administrasi Pendidikan 55-56

23 Http/ Multazam-einstain. Blogspot.id/2013/o7/ hadis tentang pendidikan dan pengajaran

24 Ahmad sanusi, pembaharuan strategi pendidikan, filsafat, manajemen dan arah pembagunan karakter bangsa, ( bandung : Nuansa Cendekia, 2014) 184

${ }^{25}$ David, Manajemen strategic, 454. 
(input) sekolah unggul adalah siswa yang diseleksi secara ketat dengan menggunakan kriteria tertentu dan prosedur yang dapat dipertanggungjawabkan seperti prestasi superior dengan indikator nilai rapor, UAN, tes akademik dan psikotes" ${ }^{26}$

Selanjutnya, Aspek budaya juga memiliki peran dalam implementasi strategik. Marquardt dalam buku karangan usman husaini mengemukakan bahwa "setiap organisasi memiliki budaya yang mencangkup serangkaian nilai, keyakinan, sikap, kebiasaan, normal, kepribadian, ritual dan kecintaan bersama terhadap organisasi" ${ }^{27}$ Peran budaya dalam implementasi strategik sangat besar dalam mencapai kesuksesan implementasi strategik. Keberhasilan sebuah organisasi ditentukan oleh seberapa dukungan lingkungan yang diperoleh strategi dari budaya organisasi. Rohman menyatakan bahwa: "kebijakan pendidikan merupakan kebijakan publik yang mengatur khusus regulasi berkaitan dengan penyerapan sumber, alokasi dan distribusi sumber, serta pengaturan perilaku dalam pendidikan. Berdasarkan penyataan Rohman di atas dapat dijelaskan bahwa kebijakan menyatakan pengaturan perilaku yang dibuat untuk mensukseskan keberhasilan strategi yang diimplementasikan. Keberadaan lingkungan eksternal juga berpengaruh terhadap penyelenggaraan strategic Madrasah . Lingkungan eksternal Madrasah misalnya letak geografis Madrasah sangat berpengaruh pada minat masyarakat untuk menyekolahkan anaknya

Langkah Keempat adalah melakukan Evaluasi dan pengendalian strategik yang merupakan tahap akhir dalam manajemen strategik. Evaluasi merupakan penilaian terhadap kinerja dan merupakan perbandingan hasil proses kegiatan yang telah dilakukan dengan perencanaan yang telah ditetapkan sebelumnnya. . Para manajer sangat perlumengetahui kapan strategi tertentu tidak berfungsi dengan baik, evaluasi strategi berarti usaha untuk memperoleh informasi ini. Semua strategi dapat dimodifikasi di masa depan karena faktor-faktor eksteral dan internal selalu berubah.

Ada tiga aktivitas penilaian strategik yang mendasar yaitu: "(1) peninjauan ulang faktor-faktor eksternal dan internal yang

${ }^{26}$ Ibid, 71-72

${ }^{27}$ Usman, Husaini. (2013). Manajemen: Teori, Praktik, dan Riset Pendidikan. Jakarta: Bumi Aksara., 2013) 214 
menjadi landasan bagi strategik saat ini, (2) pengukuran kinerja, yaitu dengan membandingkan hasil yang diterapkan dengan hasil sebenarnya, dan (3) pengambilan langkah korektif untuk memastikan bahwa kinerja sesuai dengan rencana" ${ }^{28}$ Terlepas dari pendekatan perencanaan yang digunakan, formulasi strategi harus berlandaskan pada pemahaman secara mendalam pada pasar, kompetisi, dan lingkungan eksternal. Strategi hadir dalam berbagai bentuk. Namun demikian, strategi akan mengidentifikasi tipe-tipe barang dan jasa yang akan dijual, sumber-sumber dan teknologi yang digunakan dalam proses produksinya, metoda koordinasi usaha-usaha dan rencana-rencana untuk digunakan untuk menghasilkan kinerja yang efisien dan efektif, serta tipe-tipe aktivitas yang diambil. Richard P. Rumelt mengidentifikasi empat tolok ukur yang digunakan untuk menguji baik atau tidaknya suatu strategi, yaitu

a) Consistency: strategi tidak boleh menghadirkan sasaran dan kebijakan yang tidak konsisten.

b) Consonance: strategi harus merepresentasikan respons adamadrasahif terhadap lingkungan eksternal dan terhadap perubahan-perubahan penting yang mungkin terjadi.

c) Advantage: strategi harus memberikan peluang bagi terjadinya pembuatan atau pemeliharaan keunggulan kompetitif dalam suatu wilayah aktivitas tertentu (terpilih).

d) Feasibility: strategi tidak boleh menggunakan sumber-sumber secara berlebihan (di luar kemampuan) dan tidak boleh menghadirkan persoalan-persoalan baru yang tidak terpecahkan. $^{29}$

\section{Penutup}

Manajemen strategic adalah merupakan suatu seni dan ilmu dalam hal pembuatan (formulating, penerapan (implementing dan evaluasi (evaluating keputusan- keputusan startegis antara fungsi yang memungkinkan sebuah organisasi mencapai tujuannya pada masa mendatang.

Penerapan manajemen strategic meliputi 4 tahap yaitu melakukan Analisis lingkungan; Merumuskan strategi atau formulasi strategik yang merupakan proses penyusunan langkah-

${ }^{28}$ David, Strategic Manajemen, 506

${ }^{29}$ Taufiqurahman, Manajemen strategic, 28 
langkah ke depan mencakup pengembangan visi dan misi, identifikasi peluang dan ancaman eksternal suatu organisasi; membuat prosedur kerja; dan melakukan evaluasi dan pengendalian strategik yang merupakan tahap akhir dalam manajemen strategik. Evaluasi merupakan penilaian terhadap kinerja dan merupakan perbandingan hasil proses kegiatan yang telah dilakukan dengan perencanaan yang telah ditetapkan sebelumnnya.

\section{Daftar Pustaka}

Adilah. Shadrina, pentingya Peran Visi dan Misi Diakses dariwww.dilahshadrina.blogspot.com/203, Pada tanggal 3 A pril. 2018

Ahmad sanusi, pembaharuan strategi pendidikan, filsafat, manajemen dan arah pembagunan karakter bangsa, bandung : Nuansa Cendekia, 2014

Anwar, M. Idochi. Administras Pendidkan dan Manajemen Biaya Pendidkan Jakarta:Raja G rafindo Persada 2013

Asrohah, Hanun manajemen mutu pendidikan, Buku Perkuliahan Program S- Jurusan Kependikan Islam Fakultas Tarbiyah dan Kependidikan UIN Sunan Ampel Surabaya,

Badri Yatim, dkk. 2000. Sgarah Pekenbangan Madrasah Jakarta: Departemen Agama RI Direktorat Jenderal Pembinaan Kelembagaan Agama Islam,

Fred R. D avid, 2009. Manajemen StrategkjJakarta: Salemba Empat. 2009

Fred.R., David, Strategic Management, Seventh Edition New Jersey, Prentice Hall International, Inc. 2004

Husaini. Usman, . Manajemen: Tear, Praktik, dan Rist Pendidikan Jakarta: Bumi Aksara., 2013 
khori, Ahmad Manajemen strategic dan mutu pendidikan, Vol.1 no.1 Mei 206

Murniati \&Usman, N. Implementasi Manajemen Stratëik Dalam Perberdayaan Sekdah Menengah Kginuan Bandung: Citapustaka Media Perintis, 2009

Putra D aulay. Haidar Histansitas danEksistensi Pesantren, Sekdahdan Madrasah Yogyakarta: PT. Tiara Wacana 2001

Sondang. P. Siagian, Manajemen Stratejik. Jakarta: Bumi Aksara, 2012

Taufiqurahman, Manajemen strategic, Jakarta: Fakultas ilmu social dan politik, Universitas Prof. Dr Moestopo Beragama 2016

Usman, N \&.Murniati Implementas Manajemen Stratejik Dalam Penbedayaan Sekdah Menengah Kojunan Bandung: Citapustaka Media Perintis, 2009 